\title{
THE AFFECT OF PRODUCTION EDUCATION SYSTEM ON PRODUCTION QUALITY AND ITS APPLICATION OF A FACTORY IN AUTOMOTIVE INDUSTRY
}

\author{
Mustafa ÖZDEMIR*, Dilek Arzu AKOLAŞ * * \\ * Artvin Çoruh Üniversitesi Arhavi Meslek Yüksekokulu, **Aksaray Üniversitesi İIB \\ Fakültesi \\ E-mail: mustafaozdemir@artvin.edu.tr
}

Copyright (C) 2015 Mustafa ÖZDEMİR, Dilek Arzu AKOLAŞ. This is an open access article distributed under the Eurasian Academy of Sciences License, which permits unrestricted use, distribution, and reproduction in any medium, provided the original work is properly cited.

\begin{abstract}
Because of the complexity of the work done by the workers in the direct production or assembling departments or wide product range in the production facilities; it becomes quite difficult to produce same quality and standardized products during the manufacturing process. Nowadays, there are intense efforts in order to minimize these problems and to improve competitiveness especially in labor-intensive manufacturing facilities while competition gained momentum and importance of the quality is evolved. Businesses use a variety of techniques and methods to achieve the highest quality with minimal cost and to make the quality standardized. In addition, measurement of the effects of these methods for quality purposes is also important to show the efficiency of the performed application. The purpose of this study was made of the assembly process in production lines for measuring the impact on the technical quality of the product to be brought to standard conditions apply. First time in this context; study of the historical development of production underlying the education system, the education system in the business, quality concept and practice are discussed. Later models in the light of recovering data group analyzes were performed. Results of the analysis is devoted to comments on the findings and findings. Finally, in conjunction with the results from the recommendations and results of the research are discussed. Quantitative research methods have been preferred in the study and follow-up data were obtained from the error list of measures used in the business. The obtained data were analyzed by statistical programs. The difference between the experimental and control groups for comparison of quantitative data Man Whitney U, Wilcoxon test was used for intra-group repeated measures.
\end{abstract}

Keywords: Product, Production, Training, Quality Control,

\section{Üretim Eğitim Sisteminin Ürün Kalitesine Etkisi ve Otomotiv Sektöründe Bir Fabrika Uygulaması}

\section{ÖZET}

Üretim tesislerinde montaj ya da direkt ürün imalatında çalışanların yapacakları işlerin karmaşık olması, ürün seçeneklerinin fazla olması; imalat sürecinde aynı kalitede ve standartta işin yapılmasını oldukça zor hale getirmiştir. Rekabetin hız kazandığı, kalitenin öneminin gittikçe arttığ1 günümüzde özellikle emek yoğun üretim tesislerinde bu sorunları minimum seviyeye indirebilmek ve rekabet gücünü artırmak için yoğun bir çaba sarf 
edilmektedir. İşletmeler, en az maliyet ile en yüksek kaliteyi elde etmek ve kaliteyi standart hale getirmek için çeşitli teknikler ve yöntemler kullanmaktadır. Ayrıca bu yöntemlerin kalite üzerine etkisinin ölçülmesi yapılan uygulamanın verimliliğinin gösterilmesinde önem arz etmektedir. Bu çalışmanın amacı, üretim hatlarında yapılan montaj işlemlerinin standart duruma getirilmesi için uygulanan tekniğin ürün kalitesi üzerindeki etkisini ölçmeyi yöneliktir. Bu bağlamda ilk olarak; çalışmaya temel teşkil eden üretim eğitim sistemlerinin tarihsel gelişmelerinden, işletmelerdeki eğitim sistemlerinden, kalite kavramı ve uygulamalarından bahsedilmiştir. Daha sonra grup modeli ışığında veriler toparlanarak analizleri yapılmıştır. Analiz sonucunda elde edilen bulgular ve bulgularla ilgili yorumlara yer verilmiştir. Son olaraktan araştırmada elde edilen sonuçlar ve sonuçlarla bağlantılı önerilerden bahsedilmiştir. Çalışmada kantitatif araştırma yöntemi tercih edilmiş ve veriler işletme kapsamında kullanılan hata önlem takip listelerinden temin edilmiştir. Elde edilen veriler istatistiki programlar aracılığıyla analiz edilmiştir. Niceliksel verilerin karşılaştırılmasında deney ve kontrol grupları arasındaki farkı Man Whitney U, grup içi tekrarlı ölçümlerde Wilcoxon testi kullanılmıştır.

\section{Anahtar Kelimeler: Ürün, Üretim, Eğitim, Kalite Kontrol}

\section{GIRIŞ}

Çalışanların eğitimlerinin standart şekilde yapılmasını sağlayan uygulamalardan biri de Üretim Eğitim Sistemidir. Üretim Eğitim Sistemi montaj, makine, makine bakım onarım ve eğitim merkezi gibi birimlerde standardizasyonu, çalışan eğitimini ve mevcut proseslerin iyileştirmesini hedefleyen, çalışanların kullanımına sunulmuş bir sistemdir.

Akademik çalışmalarda literatür taramasına bakıldığında eğitimin başarıyı etkilemesi (özellikle eğitim bilimlerinde) üzerine birçok çalışma mevcut olduğu görülmektedir. Fakat sanayi sektörüne yönelik, iş standardı sağlayarak ve buna yönelik eğitimin çalışanlara verildiğinde üretim sürecindeki kaliteye etkisini ölçen ya da gözlemleyen çalışmalara pek rastlanılmamaktadir.

Üretim Eğitim Sisteminin anlatılması ve sonuçlarının tespiti; fayda ya da sonuç ölçülemediği için işletmelerin iş standardına veya çalışanların gelişmesine yönelik eğitim yatırımlarının, ekstra maliyet olarak görülmesini kısmen önleyebileceği gibi buna yönelik yatırımlarında önünü açabilecektir.

Yapılacak olan bu çalışma ile literatüre iş standart eğitiminin sanayi sektöründe kalite üzerindeki etkisi üzerine, bir uygulama kazandırılacaktır. Çıkan sonuçların tatmin edicilik derecesine göre uygulama diğer sanayi kuruluşlarına örnek teşkil edebilir.

Bu kapsamda yapılan çalışma dört bölümden oluşmaktadır. Birinci bölümde tez çalışmasının kavramsal çerçevesi oluşturularak bu bağlamda çalışmaya temel teşkil eden üretim eğitim sistemlerinin tarihsel gelişmelerinden, işletmelerdeki eğitim sistemlerinden, kalite kavramı ve uygulamalarından bahsedilmiştir. İkinci bölümde uygulamanın odak noktası olan işletmedeki üretim eğitim sistemi içeriği ve kullanımı anlatılmıştır. Daha sonra kullanılan yöntem açıklanarak yöntem ışığında üretim eğitimine katılıp sistemi kullanmaya başlayan çalışanlarla, bu eğitime katılmayıp sistemi kullanmayan çalışanların hata sayıları eğitim öncesi ve eğitim sonrası olmak üzere toplam on altı haftalık toparlanmış, elde edilen verilerin analizleri yapılarak aralarındaki anlamlılık düzeyine bakılmıştır. Üçüncü bölümde aylık bazdaki verilerin analizleri sonucunda elde ile ilgili elde edilen bulgular ve bulgular ile ilgili yorumlara yer verilmiştir. Son bölümde ise araştırma sonucunda elde edilen sonuçlar ve sonuçlarla bağlantılı önerilerden bahsedilmiştir. 


\section{KAVRAMSAL ÇERÇEVE}

Bugünün küresel iş dünyasında işletmelerin sürekli gelişen ve değişen teknolojilere ayak uydurarak rekabet avantajı elde etmek için, işletme içi veri akışını ve iletişimini hızlandırarak karar alma süreçlerini kısaltmaları gerekmektedir. Günümüzde otomasyon, bilgisayar teknolojileri ve işletmelerin diğer bilgi ve haberleşme teknolojilerini kullanması önemli ölçüde artmış ve gerekli hale gelmiştir. Teknolojiye uyum sağlamak günümüz modern toplumlarında, işletmelerin ve bireylerin en önemli sorunudur (A $\breve{g c a}$ ve Diğerleri, 2013:228;Akdede ve Diğerleri, 2008:4). Küresel anlamda işletmelerin, üretim teknolojilerine sahip olması tek başına yeterli olmamaktadır. Aynı zamanda teknolojiyi kullanacak nitelikli iş gücüne de ihtiyaç vardır. İş gücünün seri üretim tesislerinde kullanılan teknolojilerine uygun olarak eğitilmesi ve bu eğitimin standart hale getirilmesi, küresel pazarda işletmelere rekabet gücü kazandırabilmektedir.

Üretim sistemi denildiğinde, bir takım girdilerin (işgücü, malzeme, bilgi, enerji, vb.) belirli süreçlerden geçirilerek insan ihtiyaçlarını karşılayan mal ya da hizmetlerin oluşturulduğu bir süreçtir. Üretim sisteminin amacı, ihtiyaç ve taleplere uygun mal ve hizmet üretimi sağlamak; kaynakları ve imkânları en iyi şekilde kullanmaktır (Delikan, 2010:6). Üretimde yeni teknolojilerin kullanılması maliyeti düşürmekte ve kaliteyi artırmakta, bu ise iç ve diş pazarlarda rekabet edebilmeyi kolaylaştırmaktadır. Verimlilik düşüklüğünün nedenlerinden biri de işletmelerdeki işgücünün nitelik düzeyindeki yetersizliğidir. Niteliği oluşturan ise verilen eğitimdir.

Türkiye'de verimliliği artırmanın bir yolu da, eğitimin ve eğitim kurumlarının geliştirilip güçlendirilmesinden geçmektedir. Eğitim, insanın bugünkü ve gelecekteki yaşamına bir müdahaledir. İnsan düşünce ve davranışlarında, amaçlı olarak istenilen yönde bir değişiklik gerçekleştirme sürecidir. İnsanın ve toplumun yararı ve yarını düşünülerek uyumun ve üretkenliğin artırılmasına yönelik düşünce ve davranış değişikliğini yaratma çabasıdır. Eğitim, önceden belirlenmiş amaçlar doğrultusunda insanların düşüncelerinde, tutum ve davranışlarında, yaşamlarında belirli iyileştirme ve geliştirmeler sağlamaya yarayan sistematik bir süreçtir (Hokka Gökdemir, 2011:1). Eğitimde amaç; istenilen kaliteyi en ekonomik şekilde sağlayacak bilinç, bilgi ve becerinin kazandırılmasıdır. Eğitim programları farklı seviyelerdeki iş görenlerin kendi rollerini öğrenmelerine ve bu roller çerçevesinde faaliyetlerini planlayabilmelerine gerekli olan ortam ve koşulları sağlar. Eğitim ihtiyaçları kurumlara, görev ve sorumluluklara göre değişiklikler gösterdiği için, eğitim programlarının içeriği değişen ihtiyaçlara uygun olarak ortaya konulmalıdır. İhtiyaç duyulan eğitimin kapsamı, hali hazırdaki bilgi ve yetenek dikkate alınarak yapılan görevin özelliklerine göre belirlenir (Güldür, 2014:21).

\section{UYGULAMA VE YÖNTEM}

Otomotiv sektöründe yer alan kuruluşlar da bilgi yönetimi adına çalışanların eğitimlerini belirli sistem ya da uygulamalar üzerinden gerçekleştirmektedirler. Otomotiv sektöründe kullanım alanı bulan sistemlerden biride Üretim Eğitim Sistemidir.

Üretim Eğitim Sistemi, montaj, makine, makine bakım onarım ve eğitim merkezi gibi birimlerde standardizasyonu sağlamak, deneyimlerle kazanılan bilgilerin kaybolmasını engellemek, çalışan eğitimini ve mevcut proseslerin iyileştirmesini günlük iş akışında desteklemek amacıyla oluşturulmuş ve çalışanların kullanımına sunulmuş bir sistemdir. Çalışanların eğitimi, tüm istasyonlara ait güncel eğitim içeriklerinin içerisinde standart bir şekilde sunulduğu didaktik bir bilgi bankası aracılığıyla sağlanmakta olup, söz konusu bilgi bankasına ulaşım yalnızca intranet bağlantısı olan bilgisayarlardan ve üretim eğitim sistemi terminallerinden gerçekleşmektedir. 
Ürünlerde yüksek kaliteye ulaşmada, gerek standardize edilmiş bir eğitim süreci, gerekse çalışanların bilgilere rahatlıkla ulaşabilmeleri oldukça büyük önem taşımaktadır. İmalatta günlük işleyişlerde maalesef birçok kalite probleminin eğitim yetersizliği ya da bilgilere zamanında ulaşamamaktan kaynaklandığını görmekteyiz. Bu anlamda ÜES Bilgi Bankası, çalışanlar için gerekli tüm bilgilerin standart bir şekilde adım adım dokümante edilerek kaydedilmesi yöntemiyle çalışanları eğitimlerde desteklemekte ve intranet üzerinden her zaman ve her ortamda çalışanların kullanımına hazır bulunmaktadır.

Üretim eğitim sistemi içerisinde eğitim dokümanlarının oluşturulabilmesi için öncelikle standart proseslerin belirlenmesi gerekmektedir. Standart proseslerin belirlenmesi işlemi uzman kişilerin katkılarıyla gerçekleşmektedir.

Ortaklaşa fikir alışverişleri ile optimal proseslerin belirlenmesi, tüm vardiyalardan uzman görüşlerinin alınması ve akabinde gerçekleşen eğitimler ile süreç iyileştirme işleminin ilk adımı kendiliğinden gerçekleşmektedir. Hedef imalat birimlerinde iş akışını standart bir şekilde yansıtan bir altyapı oluşturmak ve çalışanları bu standart dokümantasyon ile eğitmektir.

Çalışana uygun işin sağlanması, işi yapan kişinin, rahat ve etkili bir şekilde çalışmasını olanaklı kılacak, zaman ve enerji kaybına olanak vermeyecek koşulların varlığına bağlıdır. Buradaki çabalar, emek unsurunun daha rasyonel bir şekilde kullanılması, kayıp ve israfların önlenmesine yönelmiştir. $\mathrm{Bu}$ kapsamda teknik iş bölümünün hangi dereceye kadar yürütüleceği, alet ve makinelerin, onları kullanacak beşeri unsurun özellikleri göz önünde bulundurularak düzenlenmesi, belirli bir işi oluşturan hareketlerin incelenmesi, gereksiz görülenlerin çıkartılması, gerekli olanların basitleştirilmesi, gerekirse sıralarının değiştirilmesi, makine, alet ve malzemenin en iyi şekilde kullanılması yani iş yerinin ve tezgâhların veya aletlerin rahat bir çalışmayı olanaklı kılacak şekilde düzenlenmesi, 1şık, 1sı, havalandırma ve gürültü gibi fiziksel koşulların insan unsurunun özelliklerine uydurulması gibi sorunlar genellikle işin personele intibakında söz konusu olan, sanayi psikolojisi alanına giren başlica konulardır (Eren, 2008:320).

Üretim eğitim sisteminin temelini oluşturan iş adımları oluştururken, sanayi psikoloji alanına giren konular öncelik kazanmaktadır. Bu yüzden Üretim eğitim sisteminde iş adımlarını yalnızca redaktör/şef redaktör kullanıcı yetkisi olan kişiler yapabilmektedir. Birimlerde bu yetkiye sahip kişiler özel nitelikler baz alınarak belirlenmektedir.

Üretim eğitim sisteminde iş adımları oluştururken temelde iş analizi yapılmaktadır. Üretim ve hizmet işlemlerinden en yüksek düzeyde yararlanabilmek için makine, malzeme ve insan gücünün aralarındaki ilişkilerin tanımlanması, ölçülmesi ve düzenlenmesine yönelik sistematik inceleme ve araştırmaların tümüne iş analizi denmektedir. İş analizinin hedefi; iş sistemlerinin incelenmesi ve düzenlenmesine ilişkin yöntemlerin çalışan kişinin işgücü ve gereksinimlerini de göz önünde bulundurarak, işin en iyileştirilmesi ve işletmenin daha ekonomik çalışmasını sağlamaktadır (Albayrak, 2001:49-63).

Eğitim içerikleri Üretim Eğitim Sisteminin temelini oluşturmaktadır. Çalışanlar, ihtiyaç duydukları montaj bilgilerine sistem içerisinde bulunan eğitim içerikler ile elde etmektedir. Hangi birimde, hangi istasyonda, hangi iş adımı, nasıl yapılmaktadır? Montaj yaparken hangi ekipman ve malzemelere ihtiyaç vardır? Bu işi yaparken kalite, iş sağlı̆̆ ve güvenliği, püf nokta konusunda dikkat edilmesi gereken hususlar nelerdir? Eğitim içeriklerinde genel olarak bu sorulara cevap bulmak mümkündür.

\section{Araştırma Yöntem ve Modeli}

$\mathrm{Bu}$ çalışmada üretim tesislerinin yoğun rekabet ortamlarında müşteriye değer sunma politikasında kaliteli ürün üretmek için iş standardizasyonun sağlanmasının önemi ve kaliteye olan etkisi ölçülmesi amaçlanmıştır. Yani firmaların iş standardizasyonu kapsamında yapmış 
olduğu yatırım ve eğitimlerinin kalite unsuruna etkisinin olumlu olup olmadığı belirlenmeye çalışılmıştır.

Araştırmada üretim eğitimine katılıp sistemi kullanmaya başlayan çalışanlarla, eğitime katılmayıp sistemi kullanmayan çalışanların eğitim öncesi ve sonrası hata sayıları veri olarak toparlanmış ve aralarındaki anlamlılık düzeyine bakılmıştır. Araştırma deseninin sembolik ifadesi aşağıda verilmiştir.

Şekil 1: Araştırma Deseni

\begin{tabular}{llllll}
\hline Grup & Ön Hatalar & Denel İşlem & \multicolumn{2}{c}{ Son Hatalar } & Analiz \\
GD & $\mathrm{Q}_{1.1}$ & ÜES & $\mathrm{Q}_{1.2}$ & $\mathrm{Q}_{\mathrm{x}}$ & \\
GK & $\mathrm{Q}_{2.1}$ & & $\mathrm{Q}_{2.2}$ & $\mathrm{Q}_{\mathrm{x}}$ & \\
\hline
\end{tabular}

Çalışma grubu İç Anadolu Bölgesi'nde bulunan otomotiv fabrikasının iki farklı departmanından oluşmaktadır. Fabrika yaklaşık \%34'lük Pazar payı ile sektörün lideri konumundadır. 1986' dan bu yana, fabrika da üretilen yaklaşık 150.000 adet çeşitli otomotiv ürünleri öncelikle iç pazarda satılmıştır. Günümüzde yaklaşık 1.600 çalışanı olan fabrikada 5 farklı mamul hattından oluşan bir mamul genişliğine sahiptir. Fabrikanın köklü organizasyon yapısı genel müdürlük altında yer alan üç bölüm müdürlüğü ve alt şefliklerden oluşmaktadır. Araştırmada fabrikanın birbirinin tamamlayıcı iki farklı birimi ele alınmıştır. Kontrol grubunu oluşturan birimde 90 çalışan bulunmaktadır. Deney grubundaki birimde ise 116 çalışan bulunmaktadir.

Grupların bu araştırmadaki işlevsel tanımları aşağıda verilmiştir:

Kontrol Grubu: Deneme grubundan bağımsız birimde çalışan ve eğitime katılmayan grup.

Deneme Grubu: Kontrol grubundan bağımsız fabrikada bulunup eğitime katılan grup

Birimler tarafından üretimi tamamlanmış ürünler; son kontrol, band kontrol, ürün kontrol, teslimat kontrol ve müşteri teslim öncesi kontrol olmak üzere beş farklı noktada kontrol edilerek hatalar kişi bazlı olarak kayıt altına alınmaktadır. Kontrollerde kullanılan cetveller fabrika kalite kontrol birimi tarafından gizlilik ilkesi gereği saklı tutulmaktadır.

Araştırmanın başlangıcında konu ile ilgili kapsamlı literatür taraması yapılmış olup işletmelerde iş eğitim süreçlerine nedenli yer verildiği belirlenmeye çalışılmıştır. Bu bilgiler 1şı̆̆ında, üretim eğitim sistemini bünyesinde bulunduran ve bu uygulamada yeni yapılanmaya giden örnek bir fabrika belirlenmiştir. Araştırmanın temelini oluşturan deney ve kontrol grupları fabrika içerisinde belirlenmiştir. Şirket gizlilik politikası gereği kontrol grubu A Üretim Bölümü, deney grubu B Üretim Bölümü olarak adlandırılmıştır. Bu gruplara uygulanan işlemler üç bölümden oluşmaktadır.

1- Ön hataların tespiti

2- Deney grubuna Üretim Eğitim Sisteminin Uygulanması

3- Son hataların tespiti

Deney ve kontrol gruplarında yer alan çalışanların 8 haftalık üretim sürecinde yapmış olduğu tüm ürünler beş farklı kalite kontrol noktasında fabrika auditörleri tarafından incelenerek çıkan çalışan kaynaklı üretim hataları excel dokümanlarda kayıt altına alınmıştır. Hataların hangi birim ve kişiye ait olduğunu belirlemede üretim çek listeleri kullanılmıştır. Üretim çek listeleri firma gizlilik politikası gereği arşivlenerek doküman kayıt sisteminde belirtildiği süre kadar saklanmaktadır. Üretim sayısı ve hata sayısı birbirini etkileyen iki değişken olduğundan dolayı her grup haftalık olarak ürün başına hata sayısı yani DPU'su hesaplanmıştır. İstatistik analizlerde DPU sayıları dikkate alınmaktadır. Birimlerin ön hata sayılarına yani ilk sekiz haftalık hata sayılarına bakıldığında; kontrol grubunun hata sayısı ortalaması 4,75; DPU'su 
ise 0,017 olarak görülmüştür (Tablo 1). Deney grubunun hata sayıs1 ise ortalama 22,5; DPU'su ise 0,08 olduğu görülmüştür. (Tablo 2). Artan üretim sayılarına göre haftalık hata sayılarında doğru orantılı olarak artışlarda gözlemlenmiştir.

Tablo 1. Kontrol Grubu Ön Hata, Üretim ve DPU Sayıları

\begin{tabular}{|c|c|c|c|c|c|c|c|c|}
\hline \multirow[b]{3}{*}{ Zaman } & \multicolumn{8}{|c|}{$\begin{array}{l}\text { A Üretim Bölümü } \\
\text { (Kontrol Grubu) }\end{array}$} \\
\hline & \multicolumn{4}{|c|}{ 1. Ay } & \multicolumn{4}{|c|}{ 2. Ay } \\
\hline & 1. Hafta & 2. Hafta & 3. Hafta & 4. Hafta & 1. Hafta & 2. Hafta & 3. Hafta & 4. Hafta \\
\hline Hata Sayısı & 4 & 4 & 4 & 9 & 4 & 3 & 3 & 7 \\
\hline Üretilen Ürün Sayısı & 176 & 264 & 264 & 265 & 305 & 306 & 306 & 309 \\
\hline$Q_{2.1}=$ DPU ( Hata Sayısı/ Ürün Sayısı) & 0,02273 & 0,01515 & 0,01515 & 0,03396 & 0,01311 & 0,0098 & 0,0098 & 0,02265 \\
\hline
\end{tabular}

Tablo 2. Deney Grubu Ön Hata, Üretim ve DPU Sayıları

\begin{tabular}{|c|c|c|c|c|c|c|c|c|}
\hline \multirow[b]{3}{*}{ Zaman } & \multicolumn{8}{|c|}{$\begin{array}{l}\text { B Üretim Bölümü } \\
\text { (Deney Grubu) }\end{array}$} \\
\hline & \multicolumn{4}{|c|}{ 1. Ay } & \multicolumn{4}{|c|}{ 2. Ay } \\
\hline & 1. Hafta & 2. Hafta & 3. Hafta & 4. Hafta & 1. Hafta & 2. Hafta & 3. Hafta & 4. Hafta \\
\hline Hata Sayısı & 12 & 8 & 15 & 38 & 26 & 27 & 20 & 34 \\
\hline Üretilen Ürün Sayısı & 176 & 264 & 264 & 265 & 305 & 306 & 306 & 309 \\
\hline$Q_{1.1}=$ DPU ( Hata Sayısı / Ürün Sayısı) & 0,06818 & 0,0303 & 0,05682 & 0,1434 & 0,08525 & 0,08824 & 0,06536 & 0,11003 \\
\hline
\end{tabular}

Deney grubunda bulunan 116 çalışana (mesai saatleri dışında) bilgisayar laboratuvarında her gün bir saat teorik, (mesai saatleri içerisinde) üretim montaj hattında pratik olmak üzere bir hafta boyunca uygulamalı olarak üretim eğitim sistemi anlatılmıştır. Eğitim süresinde çalışanların bire bir sistemi kullanarak teorik bilgileri pekiştirmeleri sağlanmaya çalışılmıştır. Verilen eğitimin içeriğinde:

$\square$ Sistemin amacı (Standardizasyon, Eğitimler, Süreç İyileştirmesi)

$\square$ Sistemdeki farklı rollerin sorumlulukları (Çalışan, (şef) redaktör ve yönetici,)

$\square$ Sistemde hangi bilgilerin mevcut olduğu (Gerek birim içerisinde, gerekse ansiklopedide)

$\square$ ÜES'e kaydolma

$\square$ Dokümantasyonun yapısı

$\square$ ÜES içeriklerine ulaşma için farklı yöntemler

$\square$ İş adımı dokümanının yapısı

$\square$ İş planları

$\square$ İyileştirme önerileri

$\square$ Kişisel yeterlilik matrisi görüntüleme

Ayrıca çalışanların aldıkları eğitim ile üretim eğitim sistem içeriğini sürekli olarak ulaşabilmesi imkanı olması için üretim alanına yakın olacak şekilde ÜES terminalleri yerleştirildi ve tüm kullanıcılara açık hale getirilmiştir.

Bir haftalık eğitim sürecinden sonra deney grubunda yer alan çalışanların sekiz haftalık üretim sürecinde yapmış olduğu tüm ürünler beş farklı kalite kontrol noktasında fabrika auditörleri tarafından incelenerek çıkan çalışan kaynaklı üretim hataları excel dokümanlarda kayıt altına alınmıştır. Aynı zamanda kontrol grubunda yer alan çalışanların da sekiz haftalık üretim sürecinde yapmış olduğu tüm ürünler beş farklı kalite kontrol noktasında fabrika auditörleri tarafından kayıt altına alınmıştır. 
Birimlerin son hata sayılarına yani son sekiz haftalık hata sayılarına bakıldığında; kontrol grubunun hata sayısı ortalama 5,25; DPU ortalaması 0,016 olarak görülmüştür (Tablo 3). Deney grubunun hata sayıs1 ortalamas1 20; DPU ortalamas1 ise 0,06 olduğu görülmüştür (Tablo 4). Üretim sayısının artmasına rağmen deney grubunun DPU ortalaması, kontrol grubunun DPU ortalamasından daha fazla düşüş olduğu görülmüştür. Bu veriler arasındaki anlamlılık istatiksel analiz ile de kısmen desteklenmiştir. Bu veriler arasındaki anlamlılık istatiksel analiz ile de kısmen desteklenmiştir.

Tablo 3. Kontrol Grubu Son Hata, Üretim ve DPU Sayıları

\begin{tabular}{|l|c|c|c|c|c|c|c|c|}
\hline & \multicolumn{6}{|c|}{ A Üretim Bölümü } \\
\hline & \multicolumn{3}{|c|}{ 3. Ay } & \multicolumn{4}{c|}{ 4. Ay } \\
\hline Zaman & \multicolumn{3}{|c|}{ (Kontrol Grubu - Eğitim Uygulanmam) } \\
\hline Hata Sayısı & 1. Hafta & 2. Hafta & 3. Hafta & 4. Hafta & 1. Hafta & 2. Hafta & 3. Hafta & 4. Hafta \\
\hline Üretilen Ürün Sayısı & 2 & 1 & 6 & 7 & 7 & 4 & 8 & 7 \\
\hline $\mathbf{Q}_{2.2}=$ DPU (Hata Sayısı/ Ürün Sayısı) & 0,00551 & 0,00309 & 0,01852 & 0,02108 & 0,02011 & 0,01342 & 0,02797 & 0,02115 \\
\hline
\end{tabular}

Tablo 4. Deney Grubu Son Hata, Üretim ve DPU Sayıları

\begin{tabular}{|c|c|c|c|c|c|c|c|c|}
\hline \multirow[b]{3}{*}{ Zaman } & \multicolumn{8}{|c|}{$\begin{array}{c}\text { B Üretim Bölümü } \\
\text { (Deney Grubu -Eğitim Uygulanmış) }\end{array}$} \\
\hline & \multicolumn{4}{|c|}{ 3. Ay } & \multicolumn{4}{|c|}{ 4. Ay } \\
\hline & 1. Hafta & 2. Hafta & 3. Hafta & 4. Hafta & 1. Hafta & 2. Hafta & 3. Hafta & 4. Hafta \\
\hline Hata Sayısı & 17 & 9 & 19 & 30 & 23 & 16 & 18 & 28 \\
\hline Üretilen Ürün Sayısı & 363 & 324 & 324 & 332 & 348 & 298 & 286 & 331 \\
\hline $\mathbf{Q}_{1.2}=$ DPU ( Hata Sayısı / Ürün Sayısı) & 0,04683 & 0,02778 & 0,05864 & 0,09036 & 0,06609 & 0,05369 & 0,06294 & 0,08459 \\
\hline
\end{tabular}

\section{VERILERIN ANALIZI VE BULGULAR}

Araştırmanın verilerinin toparlanmasında fabrika kapsamında kullanılan hata önlem takip listeleri kullanılmıştır. Hata önlem takip listelerinde pozisyon numarası, istasyon numarası, hata tanımı, hata bölgesi, hata kodu, hata sınıfı, hata tipi, hata tespit tarihi, ürün tipi, hata bilgi yeri, hata sebebi, alınan önlemler, etkinlik durumu, tekrar etme durumu, hata durumu bilgileri bulunmaktadır. Bu bilgiler auditör tarafından giriş ve takibi yapılmaktadır. Araştırmada elde edilen veriler SPSS (Statistical Package for Social Sciences) for Windows 21.0 program1 kullanılarak analiz edilmiştir. Verileri değerlendirilirken tanımlayıcı istatistiksel metotları (Sayı, Yüzde, Ortalama, Standart sapma) kullanılmıştır.

Niceliksel verilerin karşılaştırılmasında deney ve kontrol grupları arasındaki farkı Mann Whitney U, grup içi tekrarlı ölçümlerde Wilcoxon testi kullanılmıştır. Mann-Whitney U Testi, iki ilişkisiz örneklemden elde edilen puanların birbirlerinden anlamlı bir şekilde farklılık gösterip göstermediğini tespit eder. Başka bir anlatımla, bu test iki ilişkisiz grubun, ilgilenilen değişken bakımından evrende benzer dağılımlara sahip olup olmadığını test eder. "Wilcoxon" testi eşleştirilmiş gruplara ilişkin farklılıkların boyutlarını da dikkate alarak iki değişkene ait dağılımın aynı olup olmadığını test etmek amacıyla geliştirilmiş bir analiz yöntemidir.

Belirtilen testler yapılarak elde edilen bulgular \%95 güven aralığında, \%5 anlamlılık düzeyinde değerlendirilmiştir.

Deney ve kontrol grubunda yer alan çalışanların birinci ay puanları ortalamalarının grup değişkenine göre anlamlı bir farklılık gösterip göstermediğini belirlemek amacıyla yapılan Mann Whitney-U testi sonucunda grup ortalamaları arasındaki fark istatistiksel açıdan anlamlı 
bulunmuştur(Mann Whitney $U=1,000 ; p=0,042<0,05)$. Eğitim almayan çalışanların birinci ay yani ilk 4 haftalık puanları $(x=0,022)$, eğitim almışların birinci ay puanlarından $(x=0,075)$ düşük bulunmuştur. (Tablo 5)

Tablo 5. Birinci Ay Hata Dağılımları

\begin{tabular}{|l|l|l|l|l|l|l|}
\hline & Grup & N & Ort & Ss & MW & p \\
\hline \multirow{2}{*}{ Birinci Ay } & A (Ĕgitim Almamış) & 4 & 0,022 & 0,009 & \multirow{2}{*}{1,000} & \multirow{2}{*}{$\mathbf{0 , 0 4 2}$} \\
\cline { 2 - 7 } & B (Ĕgitim Almış) & 4 & 0,075 & 0,048 & & \\
\hline
\end{tabular}

Deney ve kontrol grubunda yer alan çalışanların ikinci ay puanları ortalamalarının grup değişkenine göre anlamlı bir farklılık gösterip göstermediğini belirlemek amacıyla yapılan Mann Whitney-U testi sonucunda grup ortalamaları arasındaki fark istatistiksel açıdan anlamlı bulunmuştur(Mann Whitney $\mathrm{U}=0,000 ; \quad \mathrm{p}=0,020<0,05)$. Eğitim almamış bölümdeki çalışanların ikinci ay puanları $(\mathrm{x}=0,014)$, eğitim almış çalışanların ikinci ay puanlarından $(\mathrm{x}=0,087)$ düşük bulunmuştur. (Tablo 6)

Tablo 6. İkinci Ay Hata Dağılımları

\begin{tabular}{|l|l|l|l|l|l|l|}
\hline & Grup & N & Ort & Ss & MW & p \\
\hline \multirow{2}{*}{ İkinci Ay } & A (Ĕ̆itim Almamış) & 4 & 0,014 & 0,006 & \multirow{2}{*}{0,000} & \multirow{2}{*}{$\mathbf{0 2 0}$} \\
\cline { 2 - 7 } & B (Ĕğitim Almış) & 4 & 0,087 & 0,018 & & \\
\hline
\end{tabular}

Deney ve kontrol grubunda yer alan çalışanların üçüncü ay puanları ortalamalarının grup değişkenine göre anlamlı bir farklılık gösterip göstermediğini belirlemek amacıyla yapılan Mann Whitney-U testi sonucunda grup ortalamaları arasındaki fark istatistiksel açıdan anlamlı bulunmuştur(Mann Whitney $\mathrm{U}=0,000 ; \mathrm{p}=0,021<0,05$ ). Eğitim almamış grup çalışanlarının üçüncü ay puanları $(\mathrm{x}=0,012)$, eğitim almış grup çalışanların üçüncü ay puanlarından $(\mathrm{x}=0,056)$ düşük bulunmuştur (Tablo 7).

Tablo 7. Üçüncü Ay Hata Dağılımları

\begin{tabular}{|l|l|l|l|l|l|l|}
\hline & Grup & N & Ort & Ss & MW & p \\
\hline \multirow{2}{*}{ Üçüncü Ay } & A (Eğitim Almamış) & 4 & 0,012 & 0,009 & & \\
\cline { 2 - 7 } & B (Eğitim Almış) & 4 & 0,056 & 0,026 & 0,000 & $\mathbf{0 , 0 2 1}$ \\
\hline
\end{tabular}

Deney ve kontrol grubunda yer alan çalışanların dördüncü ay puanları ortalamalarının grup değişkenine göre anlamlı bir farklılık gösterip göstermediğini belirlemek amacıyla yapılan Mann Whitney-U testi sonucunda grup ortalamaları arasındaki fark istatistiksel açıdan anlamlı bulunmuştur(Mann Whitney $U=0,000 ; p=0,021<0,05)$. Eğitim almamış grup çalışanlarının dördüncü ay puanları $(\mathrm{x}=0,021)$, eğitim almış grup çalışanların dördüncü ay puanlarından $(\mathrm{x}=0,067)$ düşük bulunmuştur (Tablo 8). 
Tablo 8. Dördüncü Ay Hata Dağılımları

\begin{tabular}{|l|l|l|l|l|l|l|}
\hline & Grup & N & Ort & Ss & MW & p \\
\hline \multirow{2}{*}{ Dördüncü Ay } & A (Eğitim Almamış) & 4 & 0,021 & 0,006 & \multirow{2}{*}{0,000} & \multirow{2}{*}{, $\mathbf{0 2 1}$} \\
\cline { 2 - 6 } & B (Eğitim Almış) & 4 & 0,067 & 0,013 & & \\
\hline
\end{tabular}

Aylar bazında; birinci ay ile ikinci ay, ikinci ay ile üçüncü ay, üçüncü ay ile dördüncü ay arasında anlamlı bir farklılığın olup olmadığını belirlemek amacıyla yapılan analiz sonrası bulgular aşağıda verilmiştir.

Tablo 9. Eğitim Almamış Grup Ölçümleri

\begin{tabular}{|l|l|l|l|l|l|l|l|}
\hline \multirow{2}{*}{ Ölçümler } & Önce & \multicolumn{3}{|l|}{ Sonra } & N & Z & p \\
\cline { 2 - 9 } & Ort & Ss & Ort & Ss & & & \\
\hline Birinci Ay - İkinci Ay & 0,022 & 0,009 & 0,014 & 0,006 & 4 & 5,214 & $\mathbf{0 , 0 1 4}$ \\
\hline İkinci Ay - Üçüncü Ay & 0,014 & 0,006 & 0,012 & 0,009 & 4 & 0,479 & 0,665 \\
\hline Üçüncü Ay - Dördüncü Ay & 0,012 & 0,009 & 0,021 & 0,006 & 4 & $-2,811$ & 0,067 \\
\hline
\end{tabular}

Eğitim almamış grupta birinci aydan ikinci aya geçişteki düşüş anlamlıdır( $(\mathrm{p}<0,05)$. Diğer hata ölçümlerinde değişim olmamıştır.

Tablo 10. Eğitim Almış Grup Ölçümleri

\begin{tabular}{|l|l|l|l|l|l|l|l|}
\hline \multirow{2}{*}{ Ölçümler } & Önce & \multicolumn{3}{l|}{ Sonra } & N & Z & \multirow{2}{*}{ p } \\
\cline { 2 - 10 } & Ort & Ss & Ort & Ss & & & \\
\hline Birinci Ay - İkinci Ay & 0,075 & 0,048 & 0,087 & 0,018 & 4 & $-0,670$ & 0,551 \\
\hline İkinci Ay - ücüncü Ay & 0,087 & 0,018 & 0,056 & 0,026 & 4 & 2,678 & 0,045 \\
\hline ücüncü Ay - Dördüncü Ay & 0,056 & 0,026 & 0,067 & 0,013 & 4 & $-1,524$ & 0,225 \\
\hline
\end{tabular}

Eğitim almış grupta ikinci aydan üçüncü aya geçişte hata oranındaki düşüş anlamlıdır $(\mathrm{p}<0,05)$. Diğer aylardaki değişimler anlamlı bulunmamıştır.

\section{SONUÇLAR VE ÖNERILER}

Çalışmadan elde edilen bulgulara göre deney grubunun hata sayısı kontrol grubundan fazla olduğu görülmüş̧ür. Aylık bazlı puanlarda ortalamalarının grup değişkenine göre anlamlı bir farklılık gösterip göstermediğini belirlemek amacıyla yapılan Mann Whitney-U testi sonucunda grup ortalamaları arasındaki fark istatistiksel açıdan anlamlı olduğu görülmüştür. Eğitim almış grubun eğitim öncesi ve sonrası aylara bakıldığında, eğitim sonrasındaki ay hata sayılarındaki düşüşün bir önceki aya göre anlamlı olduğu görülmüştür.

Gözlemler sonucunda firma tarafından kullanılan Üretim Eğitim Sisteminin yalnızca kalite üzerinde değil birçok farklı unsura da faydasının olduğu belirlenmiştir.

Sistem, işin nasıl yapılması gerektiği hakkında sadece tek bir standart sunmaktadır. Çalışanlar sistemde iş adımları için belirlenmiş olan bu standartlara göre çalışmaktadır. Böylece çalışanlar ve farklı vardiyalar arası yöntem farklılıkları engellenmiş olunmaktadır. Farklı yöntem vs. kullanımından doğabilecek olası kalite hataları en aza indirgenebilmektedir. 
Farklı makine üreticilerince hazırlanmış kullanım kılavuzları ya da farklı programlarla hazırlanmış çeşitli formatlarda (PPT, Word vs.) eğitim dokümanları yerine tek tip bir dokümantasyon şekli olması anlaşılırlık anlamında kolaylık sağlamaktadır.

Sistem içerisinde tüm bilgiler arşivlenmektedir. 20 yıl önceki çalışma standardını 20 yıl sonra sistemde görüntülemek, tüm bilgilere ulaşmak, süreçlerin geçmişini takip edebilme imkânı sunmaktadir.

Çalışanlar sorularına direkt olarak terminale gidip cevap arayabilmektedir. Konunun uzmanı kişiler şirket dışında bulunsa bile, yeterli desteği sistem üzerinden sağlanabilmektedir.

Üretim sahası kalite, çevre vb. uygunluk denetlemelerinde bilgilerin bilgisayar ortamında kayıtlı olması, kağıt şeklindeki verilerin bulunmaması hem bir düzen sağlıyor, hem de sadece güncel verilerin çalışanlara aktarılmasına katkıda bulunmaktadır.

Sistem mevcut durumun analiz edilmesi için bir veri tabanı oluşturuyor. Sistem üzerinden işin şu anki yapılış durumunu analiz edip yeni prosesleri / gerekli iyileştirmeleri belirlemek mümkün olmaktadır.

Sistemin faydalarının yanında bazı eksikleri de olduğu söylenebilir. Bu eksiklikler göz önüne alındığında iş standardizasyonu uygulamalarına yatırım yapacak firmalara bazı öneriler siralanabilir;

Kalitenin tekil bir unsur olmadığı, bütün işletme organlarını kapsadığı düşüncesi gereği olarak yapılan tüm uygulama ve çalışmalar belirli bölümlerle sınırlı kalmamalı tüm işletme dahil edilmelidir.

Uygulanacak eğitim sistemleri teorik ya da pratik konuda tam deneyimli personeller tarafından denetlenmelidir. Sistem üzerindeki bir hatalı ifade ya da ekipman çalışanların farkında olmadan yanlış bilgi öğrenmelerine bu da hata yapmalarına neden olabilmektedir.

Sistemlerin erişilebilirliği ve şeffaflığı tüm çalışanlara açık olmalıdır ki böylelikle sistem verimliliği artırılabilir. Ayrıca yapılan eğitimler ya da sistem kullanma süreleri çalışanların, çalışma sürelerine dahil edilmelidir. Aksi takdirde çalışan normal üretim zamanının dışında sistemi kullanmak için kendine zaman oluşturma mücadelesi verecek bu da motivasyon düşüklüğüne ve sistemin kullanılmamasına olumsuz etki edebilecektir.

Son olarak çalışanların eğitim süreçleri bir formaliteden ziyade gereklilik olarak görülmeli yapılacak yatırımların yüksek olmasından dolayı eğitim uygulamaları göz ardı edilmemelidir. Aksi halde firmalar, bugün ekstra maliyet olarak görülen eğitim yatırımını, gelecekte telafisi olmayan müşteri kaybı, Pazar payında küçülme gibi zararlı sonuçlar ile karşılaşabilirler.

\section{REFERENCES}

- Akdede, S., H., Turan, A., H., (2008), Bilişim Sistemlerinin Kobi'lerin Performansına Etkileri: Kaynak Temelli Yaklaşım İle Denizli İlinde Ampirik Bir Uygulama, Ankara Üniversitesi Siyasal Bilgiler Fakültesi, s.4.

- Albayrak, B., (2001), Proje Yönetimi ve Proje Danışmanlığı (1.Basım), Beta Basım:İstanbul. s.49;63.

- Ağca, V., Menteşe, A., (2013), Bir Kurumsal Kaynak Planlama Modülü Olarak İnsan Kaynakları Bilgi Sisteminin İKY ve İşletme Performansı Üzerindeki Etkisi: Bir Uygulama, Dumlupınar Üniversitesi Sosyal Bilimler Dergisi, Say1:37 s.228.

- Delikan, H., (2010), Esnek Üretim Sistemleri ve Üretim İşletmelerinde Uygulanması İle İlgili Alan Araştırması, Atılım Üniversitesi Sosyal Bilimler Enstitüsü İşletme Anabilim Dalı Yayınlanmış Yüksek Lisans Tezi, Ankara, s.6.

- Eren,, E., (2008), Örgütsel Davranış ve Yönetim Psikolojisi, ( 11. Basım), Beta Basim:İstanbul, s.320. 
- Güldür, M. M., (2014), Hazır Giyim Üretiminde Ütüleme Kalitesinin Hizmet İçi Eğitim Süreci İle İyileştirilmesi, Gazi Üniversitesi Eğitim Bilimleri Enstitüsü Giyim Endüstrisi ve Giyim Sanatları Eğitimi Bilim Dalı Yayınlanmış Doktora Tezi, Ankara, s.21.

- Hokka, Gökdemir, T., (2011), Kalkınmada Anahtar Verimlilik,Verimlilik- Eğitim İlişkisi, Kasım 2011, Sayı:275 s.2. 